\title{
PROBLEMS OF FOREST MANAGEMENT IN MUNICIPAL FORESTS OF THE CITY OF POZNAŃ
}

\author{
Roman JASZCZAK ${ }^{1}$, Sandra WAJCHMAN \\ Poznan University of Life Sciences, \\ Department of Forest Management, Poznań, Poland
}

\begin{abstract}
The article presents some selected management problems in municipal forests occurring as a result of the increasing pressure on recreation and urbanization. The object of investigation was municipal forests of the city of Poznan. A thesis was formed that the consequences of the recreational pressure can be reduced through reasonable equipment of forest areas in appropriate recreational infrastructure. The second thesis put forward an assumption that an uncontrolled urban pressure posed a threat to the stability of ecosystems of municipal forests.
\end{abstract}

Keywords: municipal forests, Poznań, recreational pressure, urban pressure, forest management

\section{INTRODUCTION}

In Poland, in accordance with art. 15 points. 7a of the Forest Act [10] forests located within the administrative boundaries of cities and only $10 \mathrm{~km}$ from the administrative borders of cities with more than 50 thousand people are considered to be protective forests. Their characteristic feature is the fact that they are fragmented and situated in close vicinity of residential, built-up areas. Treatment of these regions as green areas with no uniform management structure may result in upsetting the specificity of forest management in urban conditions. Thus, the concept of urban forestry is gaining in importance. The concept is defined as "an art, science and technique of management of trees and

\footnotetext{
${ }^{1}$ Corresponding author: University of Life Sciences, Department of Forest Management, Wojska Polskiego 71 C, 60-625 Poznan, Poland; e-mail: wajchman@up.poznan.pl, tel. +48618487664
} 
forest resources in urban ecosystems and surrounding them with the aim to secure psychological, sociological, economical and aesthetic advantages for municipal communities" [7]. The rational management of forest resources and, at the same time, making them accessible to the community living in or nearby poses a serious challenge to administrators of urban forest areas. Also increasing urban processes constitute a source of threat to municipal forests [2, $3,4,5,6]$.

\section{OBJECT OF INVESTIGATION}

The object of research covers municipal forests of the City of Poznan the total area of which exceeds 2463 ha administratively divided into the following four municipal forest ranges: Zieliniec, Antoninek, Marcelin and Strzeszynek. The dominant category of forest protection in the city are forests located in and around cities to $10 \mathrm{~km}$ from its borders (over $1760 \mathrm{ha}$ ). Water-protecting forests occupy an area of over 170 ha, while soil protection forests take up over 80 ha [8]. The administrator of the forests is the Poznań City Forest Enterprise which is a budget, self-government venture.

\section{RESEARCH OBJECTIVE AND THESES}

The paper presents selected aspects of the problems associated with conducting the forest management in urban forests in Poland. Particular attention was paid to the problem of recreation and urban pressures on forest areas, along with examples of conflicts derived from the study area. Based on the "Guidelines for the management of municipal forests of Poznań" [13] the possibility of compensating the pressure on the forest environment through the relevant activities of foresters are indicated. As a result, two theses have been formulated. The first, that urban forests executing non-productive roles should be adjusted in a rational manner to the needs of the society in terms of infrastructure for recreation, which should reduce the effects of recreational pressure. Second, that uncontrolled urban pressure constitutes a threat to the stability of urban forests.

\section{THE RECREATION AND URBAN PRESSURE IN URBAN FORESTS IN POZNAŃ}

The municipal forest infrastructure of the City of Poznan has been adjusted to changes in the way of spending leisure time and to tnew forms of recreation of the general public. In the neighbourhood of "Piatkowo Nature Reserve", an 
exercise area of 0.05 ha for 50+ was marked off. Disabled people can spend their time actively using a newly opened "Nordic Walking Pathway for the Disabled". It is situated in forests of the Malta Lake; the pathway can also be used by able-bodied people. Among advantages of its location is neighbourhood of the lake as well as excellent connection of this district with the remaining parts of the city. For residents with dogs, 3 'dog yards' with a total area of 1.37 ha were marked off.

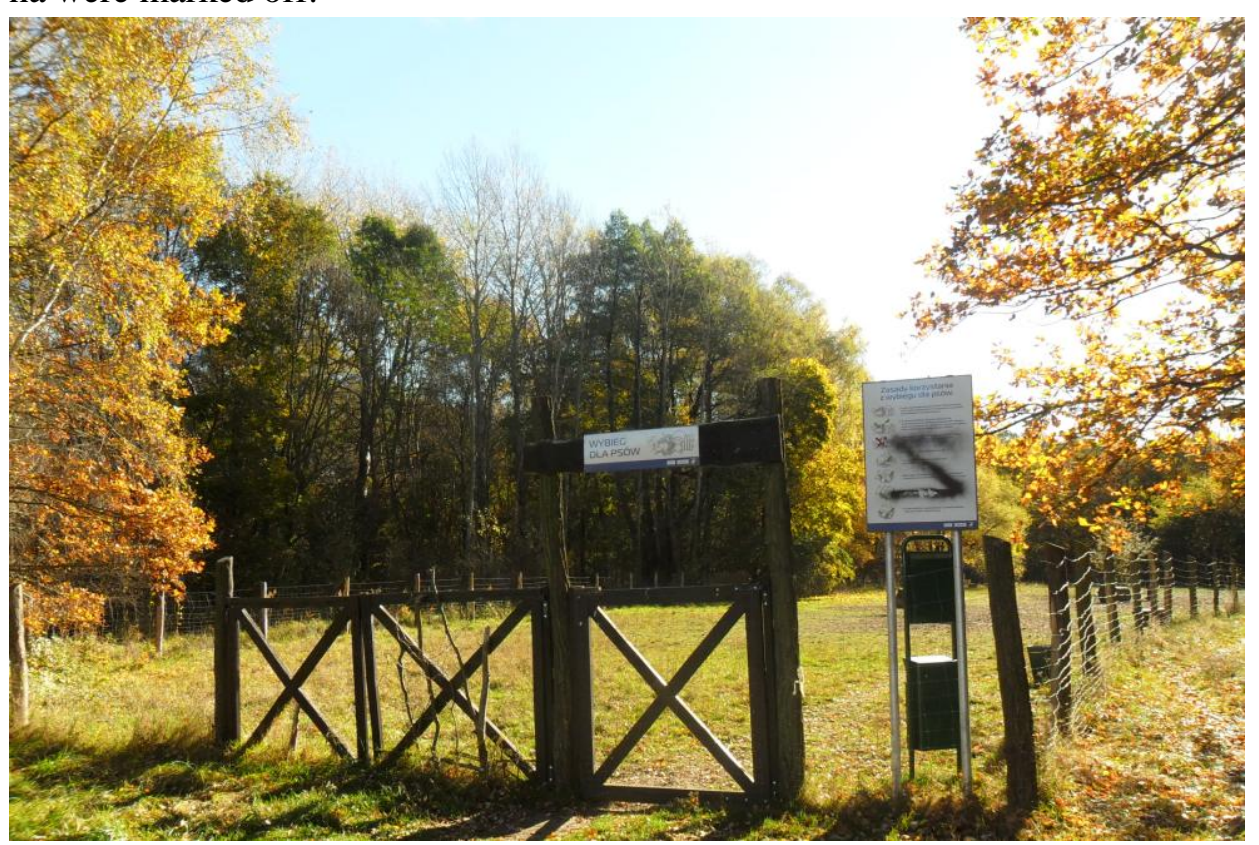

Photo 1. An enclosure for dogs (S.Wajchman, 2013r.)

Closeness of built-up areas as well as large numbers of people staying in a forest area can generate negative consequences. The impact of anthropopressure is particularly visible in the Piątkowo Forest in the area of which the "Żurawiniec Nature Reserve" is situated. The forest occupies an area of 65 ha and approximately 80000 people live in the neighbouring settlements. Among the consequences of this neighbourhood is the observed disappearance of the forest character of the region and the transformation of the area into a "forest-park" or "park". In order to protect municipal forests against this kind of transformations, the quantitative status of recreational infrastructure is monitored. It was found, on the basis of unpublished data from the Poznan Forest City Enterprise that, in the years 2002-2012 the number of some recreational facilities declined [11]. The change concerned such kind of equipment as tables, benches and bonfire sites. 


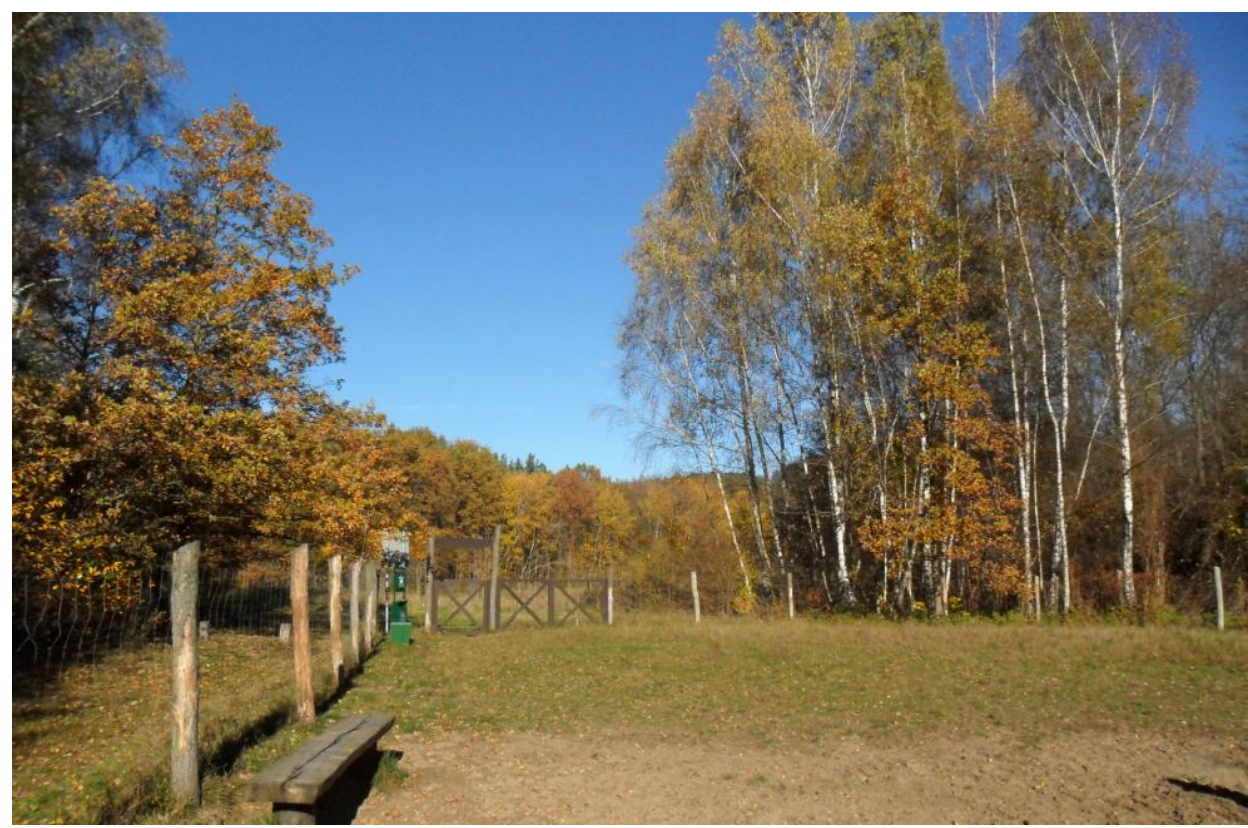

Photo 2. An enclosure for dogs (S.Wajchman, 2013r.)

Major threats to forests administered by the Poznań Forest City Enterprise resulting from strong penetration of general public included: the trampling and picking of plants, devastation of recreational equipment, signs and notice boards, damage to bushes and trees by breaking off branches and twigs as well as littering [3].

Investment pressure is one of considerable problems facing forests in urban neighbourhoods. In Poznan, conflicts arise mainly in single-family housing environs with forests which frequently, paradoxically, make future location of properties attractive. In the district of the Zieliniec municipal forest range, there was a dispute concerning the forest boundary in the neighbourhood of Darniowa Street. The forest bordering on gardening allotments which, with the passage of time, changed into building sites constituted a serious hazard in the opinion of residents. The arguments given in applications for tree fellings included: threats to human life, fears against windfalls, shading of properties etc. To make arguments for felling more credible, residents applied for the establishment of a fire-road at the expense of the forest. To assuage the conflict, instead of tree thinning, clear-cutting was carried out. Similar problems were lodged by users of the Family Gardening Allotment "Zakatek" (Strzeszynek Forest Range). Among threats posed by the forest, apart from windfalls and fires, gardeners quoted threats to garden plants resulting from direct contacts with forest trees. 
Other hazards include the shading of allotments as well as their excessive wetting.

The dispute in Miętowa Street (Zieliniec Forest Range) differed in that some residents disagreed with the ones who applied for removal of forest trees. During the period of reconstruction of some streets before "EURO 2012" Football Championships, a dispute arose in Strzegomska Street (Marcelin Forest Range). Private houses were separated from the adjacent forest by a dirt road part of which was 'developed' by residents which resulted in the narrowing of the street and expanding gardens of residents who wanted the street to be broadened at the expense of the forest. The situation was clarified thanks to the orders delivered by the Board of Municipal Roads requiring residents to pull down illegally extended fences. Sometimes, unsurfaced streets separating properties from the forest are 'developed' in a way intended to smarten up the neighbourhood. This is the case with Kiemliczów Street (Marcelin Forest Range) where masonry flower beds and new trees appeared.

In the case of all the above-mentioned examples, it is worth emphasising that all developing housing sites intrude into the neighbourhood of forests which had occupied these areas earlier. Purchase of an attractive house building site should, therefore, be well thought-over taking into account all consequences, including possible problems with the reception of television signals.

\section{TERMS OF CONDUCTING THE MANAGEMENT IN URBAN FORESTS}

Forest areas situated within the administrative confines of towns and cities constitute an attractive place of everyday recreation for local residents. Thanks to their location, they are easily accessible which means that residents can go to the forest at any time without having to organise a trip out of the town which requires time and a means of transport. This backs up the need to take into account the social function dominating in communal forests by adjusting them to recreation of local residents. Such remarks are also justified in relation to forests situated in agglomerations which, as a result of processes of urbanisation, become closer and closer to residential areas. Together with increasing numbers of people spending time in regions occupied by municipal forests, also the number of recreational forms, from the least to the most aggressive, increases. For a majority of forms of recreation, not only the location of forest in relation to populated areas is important; the occurrence of surface waters as well as the lie of the land are equally vital. Recreational pressure may upset forest ecosystems of municipal forests. Following advancing social changes, people show interests in new forms of recreation; nordic 
walking and various kinds of motor sports (e.g. quads) are gaining in popularity. Additional factors increasing attractiveness of the forest landscape which make people want to spend time there include: stand density and age, ground structure, stand species composition as well as forest site type. According to Tyrväinen et.al [9] researches a majority of participating residents preferred managed forests. The most disliked stands are those unmanaged, where young coppice limited sight and accessibility. People also dislike dead or decayed trees left remaining in a forest. So, it seems that landscape preferences are rather stable. Changes in social demography cause that together with growing longevity, increasing numbers of people become interested in healthy lifestyles which means that there are diverse preferences of individual age groups regarding ways of spending time actively. Spots intended for physical activities of senior citizens are rapidly gaining in popularity, especially close to urban residential areas. It can be said that the superiority of the recreational role of forests situated in an urban area is a function of demographic, landscape and social transformations. They should realise the tasks associated with supporting this role, primarily, by shaping and maintaining 'tall green areas' within administrative boundaries of towns and cities. Well-organised nature-forest education of the general public will help keep stability of ecosystems which surround their place of residence $[1,2,3,4,5]$.

Among frequent problems making consistent forest management difficult in municipal forests is fragmentation of ownership conditions. For effective protection, it would be appropriate to establish categories in the entire forest complex, irrespective of the form of ownership. This situation, additionally, contributes to problems with the compatibility of geodesic files.

A significant role is played by the legal bases of documents for municipal forests [12]. The type of documentation depends, first and foremost, on the form of land ownership and its size. Forests which are owned by local selfgovernments require only a simplified forest management plan for forest areas of a given town which needs to be approved by starosts after securing the opinion of the territorially appropriate head forester [10]. In the case of forests owned by the State, a full version of the forest management plan is prepared to be approved by the minister of the environment.

The adjustment of municipal forest areas to requirements of the general public is also important from the point of view of their simultaneous protection. The establishment of the scope of accessibility of forests to general public and the delimitation of recreational zones make it possible to elaborate regulations associated with fire fighting protection [14]. Forests situated within administrative boundaries of towns require different silvicultural procedures. The main objective should be to create the possibility of providing social 
functions. A significant role therefore relates to the work of regeneration felling and thinning. The determination of the method of natural-engineering management is predetermined by production possibilities of sites, requirements resulting from the role of the forest in the landscape as well as by the adapted silvicultural plan.

\section{DIRECTIONS OF MANAGEMENT IN FORESTS OF THE CITY OF POZNAŃ}

In order to improve the management effectiveness of the municipal forests in Poznań, "Guidelines regarding the management of communal forests of the City of Poznan'" were elaborated [13]. In the document, the following four strategic objectives of management of the city's communal forests were formulated:

- protection of forest resources of the City of Poznan,

- maintenance of biodiversity and safeguarding appropriate age structure and species composition, in other words, management in accordance with principles of universal forest protection,

- adaptation of communal forests to the growing requirements of the general public in the field of rest and recreation,

- demonstration of dissimilarities of functions and methods of management in communal forests in comparison with state forests.

In recommendations concerning silviculture, the dominant recreational functions of these forests were taken into consideration: "In forests, in which recreational functions prevail, an appropriate selection of tree species for renovations, reforestation, additional forest plantings, supplemental plantings and underplanting is of particular importance. Such a selection aims at optimal forest formation with respect to the diversification of its species composition, landscape functions as well as to the formation of ecological and social forest functions".

With regard to stand maintenance and reconstruction, the following remarks deserve attention [13]:

- "In forests with dominant recreational functions in towns as well as in urban agglomerations, forest maintenance aims at continuous improvement of silvicultural, sanitary and landscape features in the course of the entire period of stand growth and development in accordance with appropriate developmental phases. Basically, 'Silvicultural principles' should be followed adapting them to the requirements of recreational forests". 
- "Communal forests, because of their changing site situation, must undergo reconstruction which takes place under the cover of the stand and is of partial nature".

In the field of fire-fighting of municipal forests, their frequent location along town streets is emphasised which facilitates access to individual sections. Both the selected strategic targets as well as the remaining recommendations provide a theoretic basis for actions which are verified in practice in conditions of social disputes and arguments as well as excessive pressure of general public.

\section{CONCLUSION}

1. Uncontrolled urban pressure and realization of non-productive function is a threat to the sustainability of urban forests. The way of minimizing damages is appropriate development in terms of tourism and recreation, and forest education of society.

2. The implementation of recreational function of forests should include the revitalization of urban habitats, protection of biodiversity and the development of an attractive, multi-species stand structure.

3. Guidelines for the management of municipal forests the city of Poznan are pioneering in the whole country. They take into account the specific characteristics and potential threats to urban forests, the principles of forest management are prepared according to these conditions.

\section{ADDITIONAL INFORMATION}
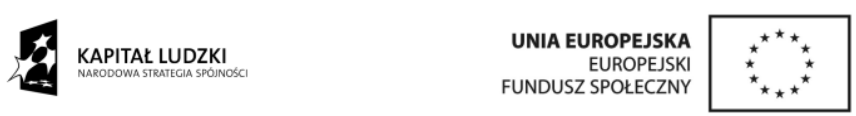

Man - the best investment

Publication co-financed by the European Union within the European Social Fund.

* Co-author Sandra Wajchman is a scholarship holder within the project "Scholarship support for PhD students specializing in majors strategic for Wielkopolska's development”, Sub-measure 8.2.2 Human Capital Operational Programme, co-financed by European Union under the European Social Fund. 


\section{REFERENCES}

1. Hunter I. R.: What do people want from urban forestry? - The European experience. Urban Ecosytems, 5 (2001), 277-284.

2. Jaszczak R.: Las $i$ gospodarka leśna $w$ zasięgu oddziaływania miast $w$ Polsce. Studia i Materiały Centrum Edukacji Przyrodniczo-Leśnej. R. 10, Z. 3, 19 (2008), 152-171.

3. Jaszczak R., Beker C., Gołojuch P.: Leśnictwo i gospodarka leśna na obszarze aglomeracji poznańskiej, red. R. Jaszczak, Bogucki Wyd. Naukowe, Poznań 2010.

4. Jaszczak R., Beker C., Gołojuch P., Miotke M.: Forest education of the urban population in Poland as exemplified by Poznan agglomeration. Journal of Management and Sustainable Development 2, 29 (2011a), 97102.

5. Jaszczak R., Beker C., Gołojuch P., Miotke M.: Preconditioning of forest economy in Poland in urban areas. Journal of Management and Sustainable Development 2, 29 (2011b), 107-111.

6. Konijnendijk C. C.: Adapting forestry to urban demands - role of communication in urban forestry in Europe. Landscape and Urban Planning, 52 (2000), 89-100.

7. Miller R.W.: Urban Forestry: Planning and Managing Urban Green Spaces. Second Edition, New Jersey, Prentice Hall 1997.

8. Plan urzadzenia lasu komunalnego miasta Poznania 2002-2012. BULiGL. Poznań, 2001.

9. Tyrväinen. T, S. Harri, and O. Kolehmainen: Ecological and aesthetic values in urban forest management. Urban For. Urban Green. 1 (2003), 135149.

10. Ustawa o lasach z dn. 28 września 1991 r. Dz.U. 1991 nr 101 poz. 444 z późn.zm.

11. Wajchman S.: Rekreacyjne zagospodarowanie lasów miejskich miasta Poznania. Studia i Materiały CEPL R.15 Zeszyt 34/1/2013, 119-125

12. Ważyński B.: Urzqdzanie i rekreacyjne zagospodarowanie lasu. Poradnik leśnika. PWRiL Warszawa 2011.

13. Wytyczne dotyczqce gospodarowania lasami komunalnymi miasta Poznania. Załącznik do zarządzenia Nr 183/2012/P Prezydenta Miasta Poznania z dn.19.03.2012 r. Poznań 2012.

14. Zasady hodowli lasu. PGL LP. Centrum Informacyjne LP, Warszawa 2012. 


\section{PROBLEMY GOSPODARKI W LASACH MIEJSKICH NA PRZYKŁADZIE OBSZARÓW LEŚNYCH MIASTA POZNANIA}

\section{Streszczenie}

W artykule przedstawiono wybrane problemy gospodarki w lasach miejskich na przykładzie obszarów leśnych miasta Poznania. Postawiono tezę, że skutki presji rekreacyjnej mogą być ograniczane poprzez racjonalne wyposażanie terenów leśnych w infrastrukturę rekreacyjną. Drugą tezą było stwierdzenie, iż niekontrolowana presja urbanizacyjna stanowi zagrożenie dla stabilności lasów miejskich. Przedstawiono wybrane zapisy „Wytycznych dotyczących gospodarowania lasami komunalnymi miasta Poznania". Dokument traktuje o gospodarce leśnej miasta Poznania i zawiera teoretyczne wytyczne do jej prowadzenia. Artykuł nawiązuje do rekreacyjnego zagospodarowania lasów Poznania i przedstawia kształtowanie w tym zakresie infrastruktury w oparciu o zmieniające się preferencje sposobu spędzania czasu na miejskich terenach leśnych.

Słowa kluczowe: lasy miejskie, Poznań, presja miejska, presja rekreacyjna, urządzanie lasu

Editor received the manuscript: $\quad 26.01 .2014$ 